\title{
Effects of Selective Estrogen Receptor Modulators on Plasma Membrane Estrogen Receptors and Catecholamine Synthesis and Secretion in Cultured Bovine Adrenal Medullary Cells
}

\author{
Hirohide Inagaki ${ }^{1,4}$, Yumiko Toyohira ${ }^{1}$, Keita Takahashi ${ }^{1}$, Susumu Ueno ${ }^{2}$, Go Obara ${ }^{3}$, Toshinori Kawagoe ${ }^{4}$, \\ Masato Tsutsui ${ }^{5}$, Toru Hachisuga ${ }^{4}$, and Nobuyuki Yanagihara ${ }^{1, *}$ \\ ${ }^{1}$ Department of Pharmacology, School of Medicine, ${ }^{2}$ Department of Occupational Toxicology, Institute of Industrial \\ Ecological Sciences, ${ }^{3}$ Department of Anesthesiology, School of Medicine, ${ }^{4}$ Department of Obstetrics and Gynecology, \\ School of Medicine, University of Occupational and Environmental Health, 1-1, Iseigaoka, Yahatanishi-ku, \\ Kitakyushu 807-8555, Japan \\ ${ }^{5}$ Department of Pharmacology, Graduate School of Medicine, University of The Ryukyus, Okinawa 903-0215, Japan
}

Received August 28, 2013; Accepted November 7, 2013

\begin{abstract}
We previously reported the occurrence and function of plasma membrane estrogen receptors in cultured bovine adrenal medullary cells. Here we report the effects of raloxifene and tamoxifen, selective estrogen receptor modulators, on plasma membrane estrogen receptors and catecholamine synthesis and secretion in these cells. Raloxifene caused dual effects on the specific binding of $\left[{ }^{3} \mathrm{H}\right] 17 \beta$-estradiol to the plasma membranes isolated from bovine adrenal medulla; that is, it had a stimulatory effect at $1.0-10 \mathrm{nM}$ but an inhibitory effect at $1.0-10 \mu \mathrm{M}$, whereas tamoxifen $(1.0 \mathrm{nM}-10 \mu \mathrm{M})$ increased binding at all concentrations (except for $100 \mathrm{nM}$ ). Tamoxifen at $100 \mathrm{nM}$ caused a significant increase in basal ${ }^{14} \mathrm{C}$-catecholamine synthesis from $\left[{ }^{14} \mathrm{C}\right]$ tyrosine, whereas tamoxifen and raloxifene at higher concentrations attenuated basal and acetylcholine-induced ${ }^{14} \mathrm{C}$-catecholamine synthesis. Raloxifene $(0.3,1.0$, and $3-100 \mu \mathrm{M})$ and tamoxifen $(10-100 \mu \mathrm{M})$ also suppressed catecholamine secretion and ${ }^{45} \mathrm{Ca}^{2+}$ and ${ }^{22} \mathrm{Na}^{+}$influx, respectively, induced by acetylcholine. Raloxifene $(1.0 \mu \mathrm{M})$ inhibited $\mathrm{Na}^{+}$current evoked by acetylcholine in Xenopus oocytes expressing $\alpha 4 \beta 2$ neuronal nicotinic acetylcholine receptors. The present findings suggest that raloxifene and tamoxifen at low concentrations allosterically modulate plasma membrane estrogen receptors and at high concentrations inhibit acetylcholineinduced catecholamine synthesis and secretion by inhibiting $\mathrm{Na}^{+}$and $\mathrm{Ca}^{2+}$ influx in bovine adrenal medulla.
\end{abstract}

Keywords: adrenal medulla, catecholamine synthesis and secretion, plasma membrane estrogen receptor, raloxifene, selective estrogen receptor modulator

\section{Introduction}

Selective estrogen receptor modulators (SERMs) are compounds that bind to nuclear or classical estrogen receptors (ERs) and exert either estrogenic or antiestrogenic effects depending on the specific organs $(1,2)$. At present, at least two SERMs, tamoxifen for the treatment and prevention of breast cancer and raloxi-

*Corresponding author. yanagin@med.uoeh-u.ac.jp Published online in J-STAGE on December 27, 2013 doi: $10.1254 /$ jphs.13155FP fene for the prevention of osteoporosis, are clinically available in Japan (3). Although the precise molecular mechanisms by which SERMs exert their clinical effects are unknown, their estrogenic or anti-estrogenic actions at target tissues are mediated through two ERs, ER $\alpha$, and $\operatorname{ER} \beta$ (4). In addition to the genomic ER actions, several lines of evidence have shown that SERMs acutely modulate ionic current through neuronal nicotinic acetylcholine receptors (nAChRs)-ion channels $(5,6)$ and also modulate functions of the cardiovascular systems (3). Furthermore, estrogens and raloxifene are reported to inhibit catecholamine secretion from rat and bovine 
adrenal medullary cells (7) and PC12 cells (8). These results suggest that SERMs directly affect ion channels and subsequent cellular functions in a non-genomic manner.

Adrenal medullary cells are derived from the embryonic neural crest and share many physiological and pharmacological properties with postganglionic sympathetic neurons. Stimulation of AChRs in the cells increases the synthesis of catecholamines and causes the secretion of catecholamines into the systemic circulation $(9,10)$. In bovine adrenal medullary cells, at least three distinct types of ionic channels are involved in catecholamine secretion (11): nAChR-ion channels, voltagedependent $\mathrm{Na}^{+}$channels, and voltage-dependent $\mathrm{Ca}^{2+}$ channels. In these cells, previous studies have shown that either carbachol (a synthetic derivative of ACh)-induced $\mathrm{Na}^{+}$influx via nAChR-ion channels or veratridineinduced $\mathrm{Na}^{+}$influx via voltage-dependent $\mathrm{Na}^{+}$channels increases $\mathrm{Ca}^{2+}$ influx via voltage-dependent $\mathrm{Ca}^{2+}$ channels, a prerequisite for the secretion $(7,11)$ and synthesis (10) of catecholamines. In contrast, high $\mathrm{K}^{+}$directly gates voltage-dependent $\mathrm{Ca}^{2+}$ channels to increase $\mathrm{Ca}^{2+}$ influx without increasing $\mathrm{Na}^{+}$influx (11).

Previously, we reported the occurrence and pharmacological characterization of estrogen receptors in the plasma membrane of bovine adrenal medulla (12). Furthermore, phytoestrogens such as daidzein (13) and resveratrol (14) increased catecholamine synthesis through the plasma membrane estrogen receptors. In the present study, we examined the effects of two SERMs, raloxifene and tamoxifen, on $\left[{ }^{3} \mathrm{H}\right] 17 \beta$-estradiol $\left(17 \beta-\mathrm{E}_{2}\right)$ binding to the membrane estrogen receptors, as well as catecholamine synthesis and secretion in cultured bovine adrenal medullary cells. We found that SERMs allosterically modulate $\left[{ }^{3} \mathrm{H}\right] 17 \beta-\mathrm{E}_{2}$ binding to plasma membrane estrogen receptors and positively or negatively influence catecholamine synthesis and secretion in the cells.

\section{Materials and Methods}

\section{Materials}

Oxygenated Krebs-Ringer phosphate (KRP) buffer was used throughout. Its composition is as follows: $154 \mathrm{mM}$ $\mathrm{NaCl}, 5.6 \mathrm{mM} \mathrm{KCl}, 1.1 \mathrm{mM} \mathrm{MgSO}_{4}, 2.2 \mathrm{mM} \mathrm{CaCl}_{2}$, $0.85 \mathrm{mM} \mathrm{NaH} \mathrm{PO}_{4}, 2.15 \mathrm{mM} \mathrm{Na}_{2} \mathrm{HPO}_{4}$, and $10 \mathrm{mM}$ glucose, adjusted $\mathrm{pH}$ to 7.4. Reagents were obtained from the following sources: Eagle's minimum essential medium (MEM) (Nissui Pharmaceutical, Tokyo); calf serum (Cell Culture Technologies, Zürich, Switzerland); collagenase (Nitta Zerachin, Osaka); raloxifene, tamoxifen, $17 \beta-\mathrm{E}_{2}, \mathrm{ACh}$, veratridine (Sigma Chemical Co., St. Louis, MO, USA); $\left[2,4,6,7-{ }^{3} \mathrm{H}\right] 17 \beta-\mathrm{E}_{2} \quad(3515 \mathrm{GBq} / \mathrm{mmol})$, $\left[{ }^{22} \mathrm{Na}\right] \mathrm{Cl},\left[{ }^{45} \mathrm{Ca}\right] \mathrm{Cl}_{2}$, and $\mathrm{L}-\left[\mathrm{U}-{ }^{14} \mathrm{C}\right]$ tyrosine (Perkin-Elmer,
Ltd., Boston, MA, USA). Raloxifene and tamoxifen were dissolved in $100 \%$ dimethyl sulfoxide and then diluted in a reaction medium before use at a final concentration of dimethyl sulfoxide not exceeding $0.5 \%$ unless otherwise specified.

\section{Isolation and primary culture of bovine adrenal medul- lary cells}

Bovine adrenal medullary cells were isolated by collagenase digestion of adrenal medullary slices according to the previously reported method $(15,16)$. Cells were suspended in Eagle's MEM containing 10\% calf serum, $3 \mu \mathrm{M}$ cytosine arabinoside, and several antibiotics, and maintained in monolayer culture at a density of $4 \times 10^{6}$ cells per dish ( $35 \mathrm{~mm}$ dish; Falcon, Becton Dickinson Labware, Franklin Lakes, NJ, USA) or $10^{6}$ cells per well (24-well plate; Corning Life Science, Lowell, MA, USA) at $37^{\circ} \mathrm{C}$ under a humidified atmosphere of $5 \% \mathrm{CO}_{2}$ and $95 \%$ air. The cells were used for experiments between 2 and 5 days of culture.

\section{$\left[{ }^{3} H\right] 17 \beta-E_{2}$ binding to plasma membranes isolated from adrenal medulla}

Plasma membranes were isolated from bovine adrenal medulla as described previously $(12,13)$. The specific binding of $\left[{ }^{3} \mathrm{H}\right] 17 \beta-\mathrm{E}_{2}$ was determined by incubating plasma membranes (30 $\mu \mathrm{g}$ protein) in Krebs-Ringer HEPES (KRH) buffer (composition: $125 \mathrm{mM} \mathrm{NaCl}$, $4.8 \mathrm{mM} \mathrm{KCl}, 2.6 \mathrm{mM} \mathrm{CaCl}_{2}, 1.2 \mathrm{mM} \mathrm{MgSO}_{4}, 5.6 \mathrm{mM}$ glucose, and $25 \mathrm{mM}$ HEPES-Tris, $\mathrm{pH}$ 7.4) (final volume of $200 \mu \mathrm{L})$ with various concentrations $(0.001-10 \mu \mathrm{M})$ of raloxifene or tamoxifen and $\left[{ }^{3} \mathrm{H}\right] 17 \beta-\mathrm{E}_{2}(5 \mathrm{nM}$, $0.1 \mu \mathrm{Ci}$ ) at $4^{\circ} \mathrm{C}$ for $30 \mathrm{~min}$. Then $\left[{ }^{3} \mathrm{H}\right] 17 \beta-\mathrm{E}_{2}$ bound to the membranes was separated from free ligand by filtration through a GF/C glass fiber filter (Whatman, Maidstone, UK), and the filter was washed 3 times with the ice-cold binding buffer. Specific binding of $\left[{ }^{3} \mathrm{H}\right] 17 \beta-\mathrm{E}_{2}$ was defined as the total binding minus non-specific binding, which was determined in the presence of $17 \beta-\mathrm{E}_{2}$ $(1.0 \mu \mathrm{M})(12)$.

\section{${ }^{14} \mathrm{C}$-catecholamine synthesis from $\left[{ }^{14} \mathrm{C}\right]$ tyrosine in the cells}

After preincubation for $10 \mathrm{~min}$, cells were incubated with $20 \mu \mathrm{M} \mathrm{L}-\left[\mathrm{U}_{-}{ }^{14} \mathrm{C}\right]$ tyrosine $(1 \mu \mathrm{Ci})$ in $\mathrm{KRP}$ buffer in the presence or absence of various concentrations of raloxifene or tamoxifen and $300 \mu \mathrm{M} \mathrm{ACh}$ at $37^{\circ} \mathrm{C}$ for $20 \mathrm{~min}$. After removing the incubation medium by aspiration, cells were harvested in $0.4 \mathrm{M}$ perchloric acid and centrifuged at $1600 \times g$ for $10 \mathrm{~min} .{ }^{14} \mathrm{C}$-Labelled catechol compounds were separated further by ion exchange chromatography on Duolite C-25 columns $\left(\mathrm{H}^{+}\right.$-type, $\left.0.4 \times 7.0 \mathrm{~cm}\right)(10)$ and counted for the radioac- 
tivity by a Packard Tri-Carb 2900TR liquid scintillation counter. ${ }^{14} \mathrm{C}$-Catecholamine synthesis was expressed as the sum of the ${ }^{14} \mathrm{C}$-catecholamines (adrenaline, noradrenaline, and dopamine).

\section{Catecholamine secretion from cultured bovine adrenal medullary cells}

The secretion of catecholamines was measured as described previously (15). After preincubation with or without raloxifene or tamoxifen at $37^{\circ} \mathrm{C}$ for $10 \mathrm{~min}$, the cells $\left(10^{6}\right.$ per well) were incubated with or without the SERMs in the presence or absence of various secretagogues at $37^{\circ} \mathrm{C}$ for another $10 \mathrm{~min}$. After the reaction, the incubation medium was transferred immediately to a test tube containing perchloric acid (final concentration, 0.4 M). Catecholamines (noradrenaline and adrenaline) secreted into the medium were adsorbed onto aluminum hydroxide and estimated by the ethylendiamine condensation method using a fluorescence spectrophotometer (F-2500; Hitachi, Tokyo) with excitation and emission wavelengths of 420 and $540 \mathrm{~nm}$, respectively.

${ }^{22} \mathrm{Na}^{+}$and ${ }^{45} \mathrm{Ca}^{2+}$ influx by the cells

The influx of ${ }^{22} \mathrm{Na}^{+}$and ${ }^{45} \mathrm{Ca}^{2+}$ was measured as reported previously (11). After preincubation with or without raloxifene or tamoxifen at $37^{\circ} \mathrm{C}$ for $10 \mathrm{~min}$, the cells $\left(4 \times 10^{6}\right.$ per dish) were incubated with $1.5 \mu \mathrm{Ci}$ of ${ }^{22} \mathrm{NaCl}$ or $1.5 \mu \mathrm{Ci}$ of ${ }^{45} \mathrm{CaCl}_{2}$ at $37^{\circ} \mathrm{C}$ for $5 \mathrm{~min}$ in the presence or absence of $300 \mu \mathrm{M}$ ACh and various concentrations of the SERMs in KRP buffer. After incubation, the cells were washed 3 times with ice-cold KRP buffer, solubilized in $10 \%$ Triton $\mathrm{X}-100$, and counted for radioactivity of ${ }^{22} \mathrm{Na}^{+}$and ${ }^{45} \mathrm{Ca}^{2+}$ by an Aloka ARC-2005 gamma counter and a Packard Tri-Carb 2900TR liquid scintillation counter, respectively.

Expression of nAChRs in Xenopus oocytes and electrophysiological recordings

Isolation and microinjection of Xenopus oocytes was performed as described previously $(17,18)$. In brief, the cDNA encoding the $\alpha 4$ and $\beta 2$ subunits of rat neuronal nAChR, subcloned into pcDNAI/Neo (Invitogen, Carlsbad, CA, USA) vector, was kindly provided from Dr. James W. Patrick (Division of Neuroscience, Baylor College of Medicine, Houston, TX, USA). Oocytes were injected with cDNAs $(1.5 \mathrm{ng} / 30 \mathrm{~nL})$ and electrophysiological recordings were performed $2-3$ days after injection. Each oocyte was perfused $(2 \mathrm{~mL} / \mathrm{min})$ with $\mathrm{Ba}^{2+}$-Ringer's solution $(115 \mathrm{mM} \mathrm{NaCl}, 2.5 \mathrm{mM} \mathrm{KCl}$, $1.8 \mathrm{mM} \mathrm{BaCl}_{2}$, and $10 \mathrm{mM}$ HEPES, $\mathrm{pH}$ 7.4) containing $1 \mu \mathrm{M}$ atropine sulfate, to minimize the effects of secondary activated $\mathrm{Ca}^{2+}$-dependant $\mathrm{Cl}^{-}$currents and then impaled with 2 glass electrodes $(1-5 \mathrm{M} \Omega)$ filled with $3 \mathrm{M}$
$\mathrm{KCl}$ and clamped at $-70 \mathrm{mV}$ using the OC-725C Oocyte Clamp Amplifier (Harvard Apparatus, Inc., Holliston, MA, USA). ACh was applied for $30 \mathrm{~s}$ to obtain the maximum (peak) current used as a measure of drug response. We examined the effect of raloxifene $(1 \mu \mathrm{M})$ on $\mathrm{Na}^{+}$current induced by ACh at a concentration that produced $50 \%$ of the maximal effect $\left(\mathrm{EC}_{50}\right)$ of $\mathrm{ACh}$ $(1 \mathrm{mM})$.

\section{Statistical analyses}

All experiments were performed in duplicate or triplicate, and each experiment was repeated at least three times. All values are given as the mean \pm S.E.M. The significance of differences between means was evaluated using one-way analysis of variance (ANOVA). When a significant F value was found by ANOVA, Dunnett's or Scheffe's test for multiple comparisons was used to identify differences among the groups. Values were considered statistically different when the $P$-value was less than 0.05 . Statistical analyses were performed using PRISM for Windows version 5.0J software (Abacus Concept, Berkeley, CA, USA).

\section{Results}

Effects of raloxifene and tamoxifen on $\left[{ }^{3} H\right] 17 \beta-E_{2}$ binding to plasma membranes

We first examined the effects of raloxifene and tamoxifen on the specific binding of $\left[{ }^{3} \mathrm{H}\right] 17 \beta-\mathrm{E}_{2}$ to plasma membranes isolated from bovine adrenal medulla. When plasma membranes were incubated with these SERMs at various concentrations, the specific binding of $\left[{ }^{3} \mathrm{H}\right] 17 \beta-\mathrm{E}_{2}$ was significantly increased by raloxifene and tamoxifen at $1.0-10 \mathrm{nM}$ (Fig. 1A) and $1.0 \mathrm{nM}-$ $10 \mu \mathrm{M}$ (except for $100 \mathrm{nM}$ ) (Fig. 1B), respectively, but inhibited by raloxifene at $1.0-10 \mu \mathrm{M}$ (Fig. 1A). These results suggest that the SERMs interact with plasma membrane estrogen receptors to positively or negatively modulate specific $\left[{ }^{3} \mathrm{H}\right] 17 \beta$ - $\mathrm{E}_{2}$ binding.

Effects of raloxifene and tamoxifen on basal and $A C h$ induced ${ }^{14} \mathrm{C}$-catecholamine synthesis from $\left[{ }^{14} \mathrm{C}\right]$ tyrosine in the cells

Bovine adrenal medullary cells were incubated with $20 \mu \mathrm{M}\left[{ }^{14} \mathrm{C}\right]$ tyrosine in KRP buffer in the presence or absence of various concentrations of SERMs at $37^{\circ} \mathrm{C}$ for $20 \mathrm{~min}$. As shown in Fig. 2B, tamoxifen at $100 \mathrm{nM}$ significantly increased ${ }^{14} \mathrm{C}$-catecholamine synthesis from $\left[{ }^{14} \mathrm{C}\right]$ tyrosine, but raloxifene and tamoxifen at higher concentrations $(0.1-1.0$ and $1.0-10 \mu \mathrm{M}$, respectively) inhibited it (Fig. 2: A and B). Raloxifene (100 nM) and tamoxifen $(100 \mathrm{nM}$ and $1.0 \mu \mathrm{M})$ had little effect on $\left[{ }^{14} \mathrm{C}\right]$ tyrosine uptake by the cells (data not shown), 
(A)

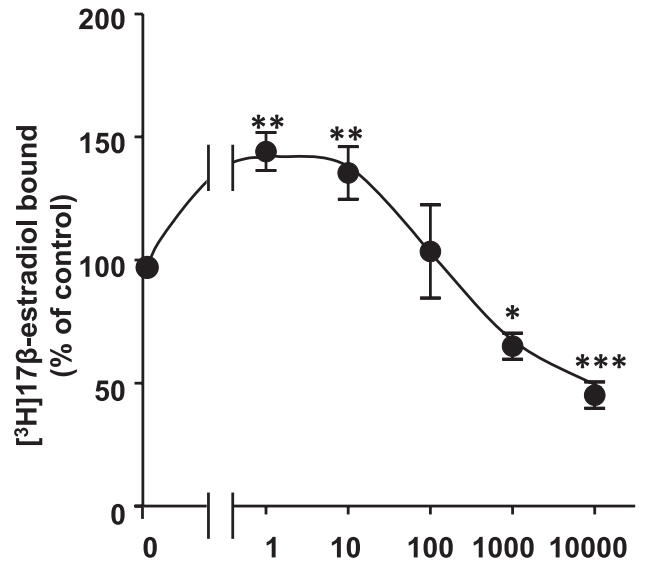

(B)

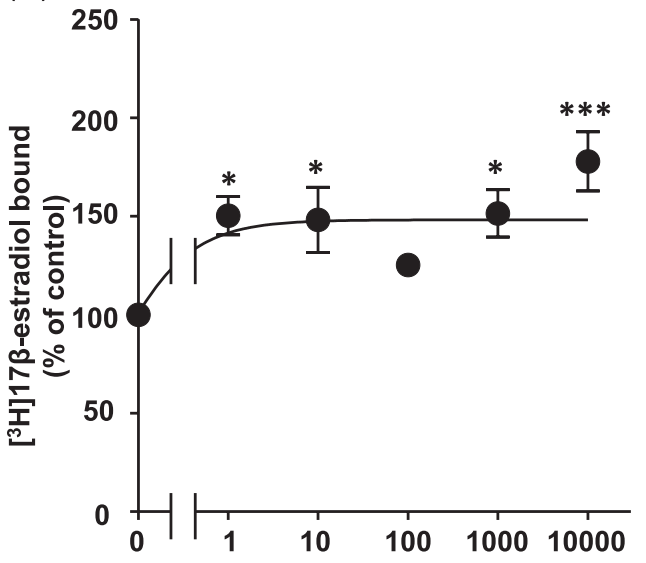

Fig. 1. Effects of raloxifene (A) and tamoxifen (B) on the specific binding of $\left[{ }^{3} \mathrm{H}\right] 17 \beta$-estradiol (17 $\beta$ - $\left.\mathrm{E}_{2}\right)$ to plasma membranes isolated from bovine adrenal medulla. Plasma membranes $(30 \mu \mathrm{g} /$ tube $)$ were incubated with $\left[{ }^{3} \mathrm{H}\right] 17 \beta-\mathrm{E}_{2}(5 \mathrm{nM})$ and various concentrations of raloxifene (A) or tamoxifen (B) for $30 \mathrm{~min}$ at $4{ }^{\circ} \mathrm{C}$. Non-specific binding of $\left[{ }^{3} \mathrm{H}\right] 17 \beta$ - $\mathrm{E}_{2}$ was determined in the presence of 200 -fold excess concentrations of $17 \beta-\mathrm{E}_{2}$, and specific binding was obtained by subtracting non-specific binding from total binding. Control specific binding of $\left[{ }^{3} \mathrm{H}\right] 17 \beta-\mathrm{E}_{2}[150 \pm 15$ (A) and $208 \pm 36$ (B) fmol/mg protein] was assigned a value of $100 \%$ and the data are expressed as $\%$ of control. Values shown are the mean \pm S.E.M. of 4 experiments carried out in duplicate. $* P<0.05, * * P<0.01$, and $* * * P<0.001$; compared to each control.

suggesting that the SERMs do not affect tyrosine uptake by the cells. ACh $(300 \mu \mathrm{M})$ increased ${ }^{14} \mathrm{C}$-catecholamine synthesis, which raloxifene and tamoxifen suppressed significantly $(1.0 \mu \mathrm{M}$ and $10-100 \mu \mathrm{M}$, respectively) in a concentration-dependent manner (Fig. 2: C and D).

\section{Effects of pretreatment with raloxifene and tamoxifen on catecholamine secretion induced by ACh in the cells}

Raloxifene $(1 \mu \mathrm{M})$ and tamoxifen $(10 \mu \mathrm{M})$ did not significantly affect basal secretion of catecholamines ( control $=2.85 \% \pm 0.17 \%$, raloxifene $=3.21 \% \pm 0.41 \%$, tamoxifen $=3.47 \% \pm 0.23 \%$ of the total catecholamines). Stimulation of nAChR-ion channels by ACh, a physiological secretagogue, caused catecholamine secretion corresponding to $16.79 \% \pm 0.75 \%$ of the total catecholamines in the cells (Fig. 3A). Pretreatment of cells with raloxifene $(1 \mu \mathrm{M})$ (Fig. 3A) and tamoxifen $(10 \mu \mathrm{M})$ (Fig. 3B) for $0,5,10,20$, and $30 \mathrm{~min}$ caused a timedependent decrease in catecholamine secretion induced by $\mathrm{ACh}$ for up to $30 \mathrm{~min}$, with a continuously maximal reduced level occurring at $10 \mathrm{~min}$. Therefore, the effect of SERMs on catecholamine secretion was evaluated using cells pretreated with SERMs for $10 \mathrm{~min}$.

We examined the effects of raloxifene $(1 \mu \mathrm{M})$ and tamoxifen $(10 \mu \mathrm{M})$ on catecholamine secretion induced by other secretagogues. Veratridine $(100 \mu \mathrm{M})$, an activator of voltage-dependent $\mathrm{Na}^{+}$channels, or $56 \mathrm{mM} \mathrm{K}$, an activator of voltage-dependent $\mathrm{Ca}^{2+}$ channels, caused catecholamine secretion corresponding to $24.28 \% \pm$ $1.58 \%$ and $19.47 \% \pm 1.11 \%$ of the total catecholamines, respectively (Fig. 4A). Raloxifene (1 $\mu \mathrm{M})$ (Fig. 4A) and tamoxifen $(10 \mu \mathrm{M})$ (Fig. 4B) had little effect on catecholamine secretion induced by veratridine and high $\mathrm{K}^{+}$.

Concentration-inhibition curves for the effects of raloxifene or tamoxifen on ACh-induced catecholamine secretion and ${ }^{22} \mathrm{Na}^{+}$and ${ }^{45} \mathrm{Ca}^{2+}$ influx

Pretreatment of cells with raloxifene $(0.3,1,10$, and $100 \mu \mathrm{M})$ or tamoxifen $(10,30$, and $100 \mu \mathrm{M})$ for 10 min reduced ACh-induced secretion of catecholamines to $81.0 \%, 65.0 \%, 35.1 \%$, and $33.0 \%$ (Fig. 5A) or to $49.0 \%, 43.1 \%$, and $25.4 \%$ (Fig. $6 \mathrm{~A}$ ), respectively, of $\mathrm{ACh}$ alone in a concentration-dependent manner. Raloxifene suppressed ACh $(300 \mu \mathrm{M})$-induced ${ }^{45} \mathrm{Ca}^{2+}$ influx at $1.0-100 \mu \mathrm{M}$ (Fig. 5B) and ACh $(300 \mu \mathrm{M})$ induced ${ }^{22} \mathrm{Na}^{+}$influx at $0.3-100 \mu \mathrm{M}$ (Fig. 5C). Tamoxifen also inhibited ACh-induced ${ }^{45} \mathrm{Ca}^{2+}$ influx (Fig. 6B) and ${ }^{22} \mathrm{Na}^{+}$influx at $10-100 \mu \mathrm{M}$ (Fig. 6C).

Inhibitory mode of raloxifene or tamoxifen on ${ }^{22} \mathrm{Na}^{+}$ influx induced by $A C h$

We attempted to determine whether either SERM competes with ACh for binding sites on the nAChRs. When the concentration of $\mathrm{ACh}$ in the incubation medium increased, the inhibition of ${ }^{22} \mathrm{Na}^{+}$influx induced by either SERM was not overcome by increasing concentrations $(10-300 \mu \mathrm{M})$ of $\mathrm{ACh}$ (Fig. 7: A and B), indicating that neither SERM competes with ACh for the binding sites on nAChRs. 
(A)

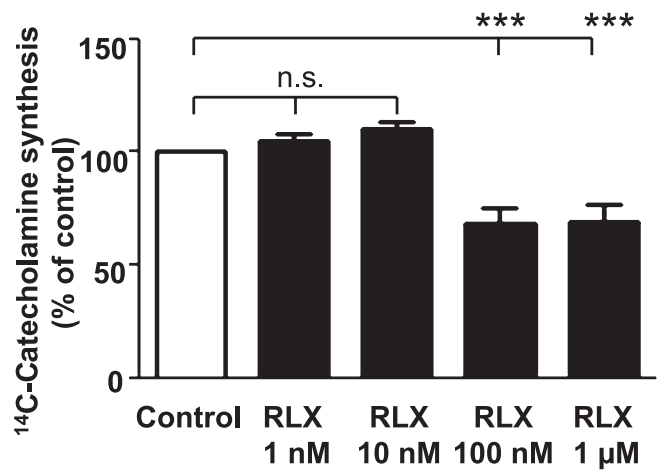

(C)

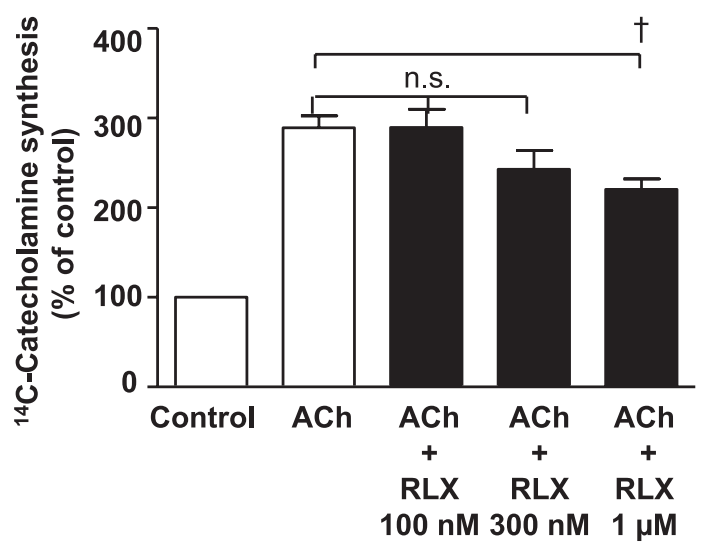

(B)

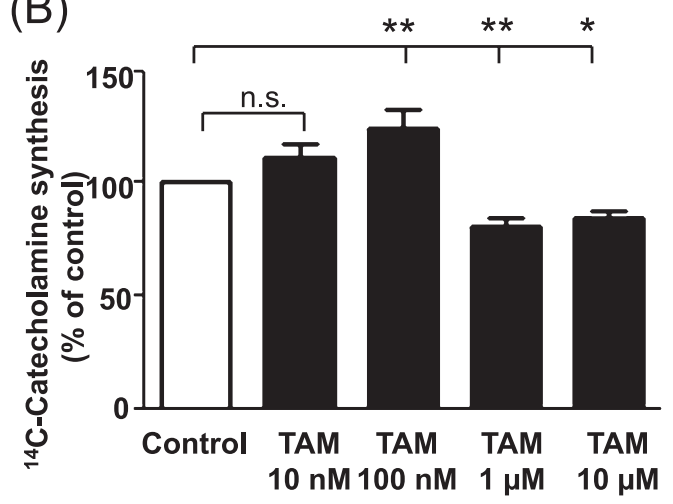

(D)

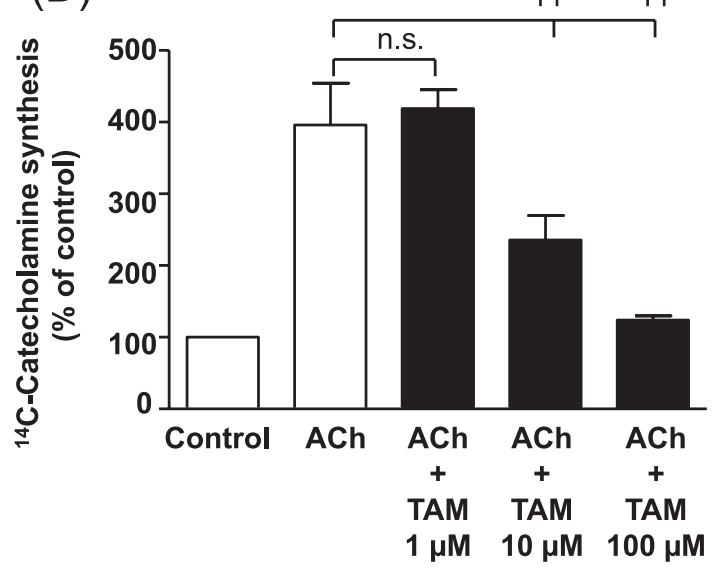

Fig. 2. Effects of raloxifene (A, C) or tamoxifen (B, D) on basal $(\mathrm{A}, \mathrm{B})$ and $\mathrm{ACh}(\mathrm{C}, \mathrm{D})$-induced ${ }^{14} \mathrm{C}$-catecholamine synthesis from $\left[{ }^{14} \mathrm{C}\right]$ tyrosine in the cells. Cells $\left(4 \times 10^{6} / \mathrm{dish}\right)$ were incubated with $\mathrm{L}-\left[\mathrm{U}-{ }^{14} \mathrm{C}\right]$ tyrosine $(20 \mu \mathrm{M}, 1 \mu \mathrm{Ci})$ and various concentrations of raloxifene (RLX) (A, C) or tamoxifen (TAM) (B, D) at $37^{\circ} \mathrm{C}$ for $20 \mathrm{~min}$ in the presence $(\mathrm{C}, \mathrm{D})$ or absence $(\mathrm{A}, \mathrm{B})$ of $\mathrm{ACh}$ $(300 \mu \mathrm{M}) .{ }^{14} \mathrm{C}$-Labelled catechol compounds were separated by ion exchange chromatography on Duolite $\mathrm{C}-25$ columns $\left(\mathrm{H}^{+}\right.$type, $0.4 \times 7.0 \mathrm{~cm}$ ) and counted for radioactivity. Control ${ }^{14} \mathrm{C}$-catecholamine synthesis $[20,500 \pm 3,900$ (A) and 20,800 $\pm 6,500$ (B) $\mathrm{dpm} / 4 \times 10^{6}$ cells $\left./ 20 \mathrm{~min}\right]$ and ACh-induced synthesis $\left[50,600 \pm 3,900(\mathrm{C})\right.$ and $112,000 \pm 8,000(\mathrm{D}) \mathrm{dpm} / 4 \times 10^{6}$ cells $/$ $20 \mathrm{~min}$ ] were assigned a value of $100 \%$ and the data are expressed as $\%$ of control or ACh. Values shown are the mean \pm S.E.M. of 4 experiments carried out in duplicate. Data are expressed as the mean \pm S.E.M. of 4 experiments carried out in triplicate. ${ }^{*} P<0.05,{ }^{* *} P<0.01$, and ${ }^{* * *} P<0.001$; compared with each control. ${ }^{\dagger} P<0.05$ and ${ }^{\dagger \dagger} P<0.01$; compared with ACh alone.

Effects of raloxifene on ACh responses in Xenopus oocytes expressing $n A C h R s$

The direct effect of raloxifene on ACh responses in Xenopus oocytes expressing rat $\alpha 4 \beta 2$ nAChRs was examined. As shown in Fig. 8, raloxifene $(1.0 \mu \mathrm{M})$ reversibly inhibited ACh-induced $\mathrm{Na}^{+}$currents.

\section{Discussion}

In the present study, we demonstrated the stimulatory or inhibitory effects of two SERMs, raloxifene and tamoxifen, on specific $\left[{ }^{3} \mathrm{H}\right] 17 \beta-\mathrm{E}_{2}$ binding to plasma membrane estrogen receptors as well as catecholamine synthesis and secretion in bovine adrenal medullary cells.
Raloxifene and tamoxifen are allosteric modulators of plasma membrane estrogen receptors

SERMs are well-known to bind to estrogen-binding sites of classical nuclear ERs to initiate changes in formation on the ER, the dissociation of the ER from heat-shock proteins, and various gene transcriptions (2). In the present study, raloxifene at $1.0-10 \mathrm{nM}$ and tamoxifen at $1.0 \mathrm{nM}-10 \mu \mathrm{M}$ except for $100 \mathrm{nM}$ rather enhanced $\left[{ }^{3} \mathrm{H}\right] 17 \beta-\mathrm{E}_{2}$ binding to plasma membrane estrogen receptors, whereas raloxifene at higher concentrations $(1.0-10 \mu \mathrm{M})$ inhibited it. This finding suggests that raloxifene and tamoxifen are an allosteric modulator of membrane estrogen receptors and that raloxifene at higher concentrations interferes with the specific binding of $\left[{ }^{3} \mathrm{H}\right] 17 \beta-\mathrm{E}_{2}$ to membrane estrogen receptors. The 
(A)

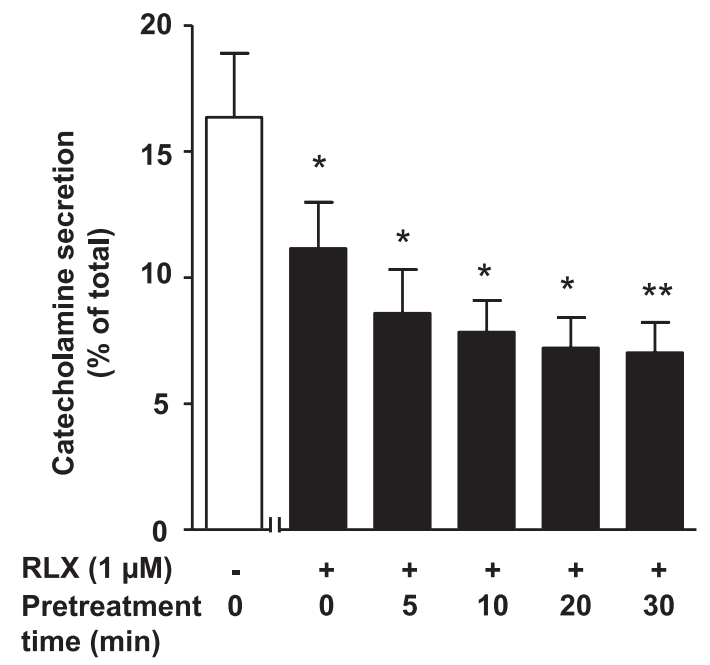

(B)

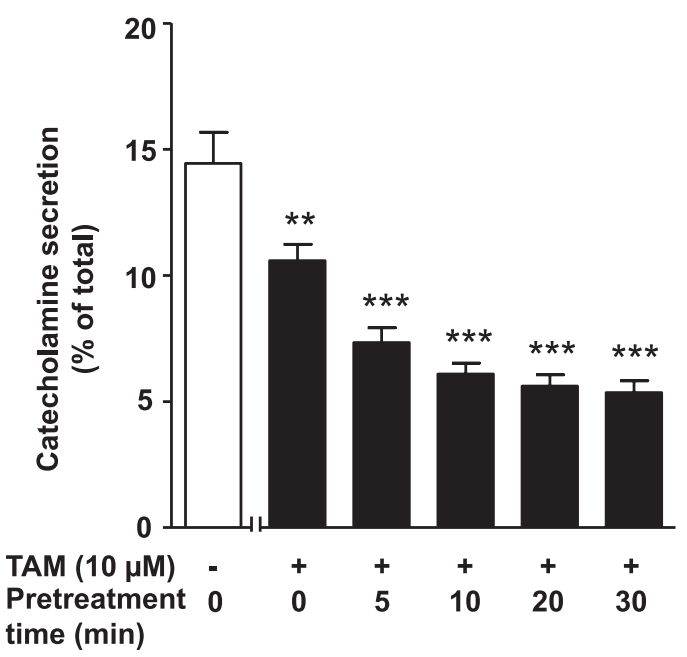

Fig. 3. Time course of pretreatment effect of raloxifene and tamoxifen on ACh-induced catecholamine secretion from the cell. After preincubation with (closed column) or without (open column) $1 \mu \mathrm{M}$ raloxifene (RLX) (A) or $10 \mu \mathrm{M}$ tamoxifen (TAM) (B) for the indicated period, the cells $\left(10^{6} /\right.$ well) were stimulated with $\mathrm{ACh}(300 \mu \mathrm{M})$ for $10 \mathrm{~min}$ at $37^{\circ} \mathrm{C}$. Catecholamines secreted into the medium were measured and expressed as a percentage of the total catecholamines [7.19 $\pm 0.98 \mu \mathrm{g}(\mathrm{A}), 7.60 \pm 0.82 \mu \mathrm{g}(\mathrm{B})]$ in the cells. Data are the mean \pm S.E.M. of 4 separate experiments carried out in triplicate. $* P<0.05, * * P<0.01$, and $* * * P<0.001$; compared with ACh alone.

(A)

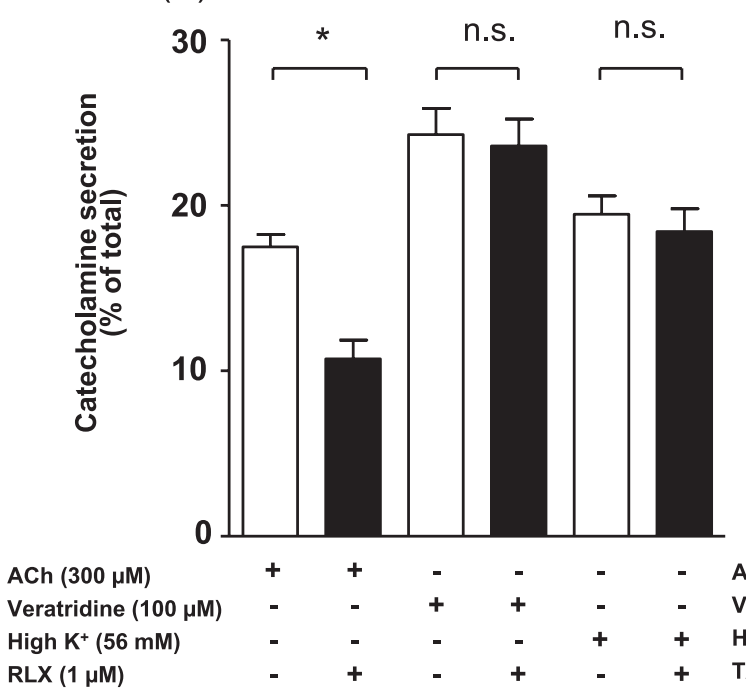

(B)

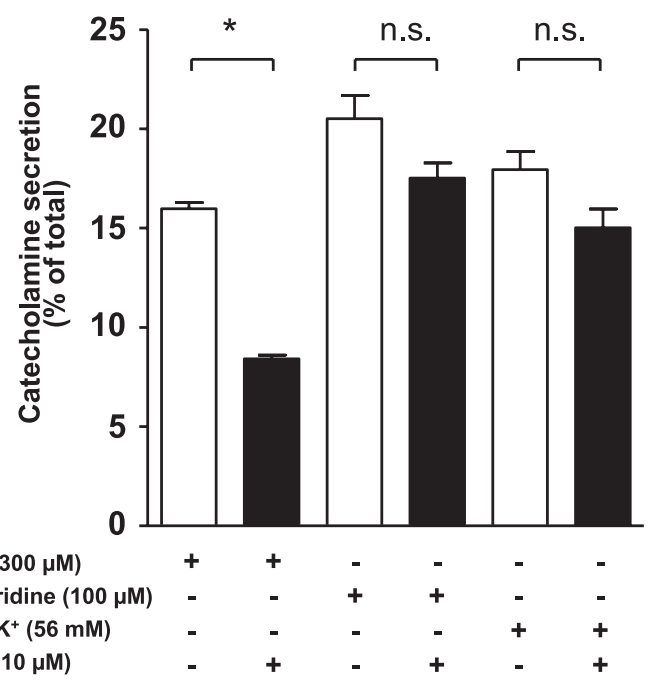

Fig. 4. Effects of raloxifene (A) or tamoxifen (B) on catecholamine secretion induced by various secretagogues. After preincubation of cells with or without raloxifene (RLX) (A) or tamoxifen (TAM) (B) for $10 \mathrm{~min}$, the cells (10\% $/$ well) were incubated with or without $\mathrm{ACh}(300 \mu \mathrm{M})$, veratridine $(100 \mu \mathrm{M})$, or high concentrations of $\mathrm{K}^{+}(56 \mathrm{mM})$ for another $10 \mathrm{~min}$ at $37^{\circ} \mathrm{C}$. Catecholamines secreted into the medium were measured and expressed as a percentage of the total catecholamines [6.21 $\pm 1.19 \mu \mathrm{g}(\mathrm{A}), 7.28 \pm 0.59 \mu \mathrm{g}$ (B)] in the cells. Data are the mean \pm S.E.M. of 4 separate experiments carried out in triplicate. $* P<0.05$, compared with ACh alone.

former result is similar to that of our previous data produced by ICI182,780, a pure antagonist of nuclear $\mathrm{ER}$, and $p$-nonylphenol or bisphenol A, environmental estrogenic pollutants, both of which allosterically enhanced specific $\left[{ }^{3} \mathrm{H}\right] 17 \beta-\mathrm{E}_{2}$ binding to plasma membrane estrogen receptors (12). 
(A)

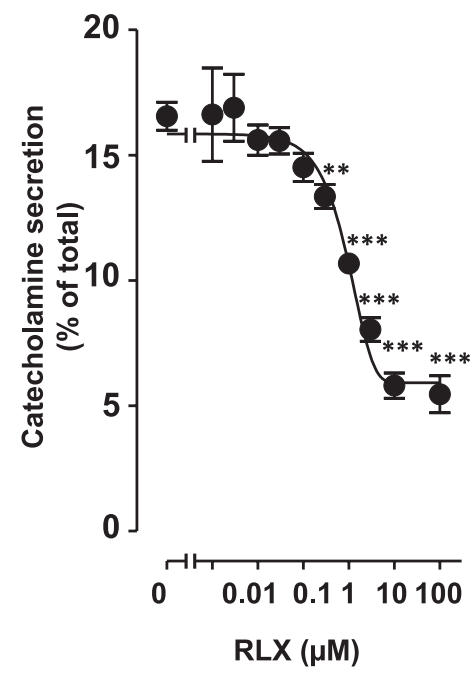

(B)

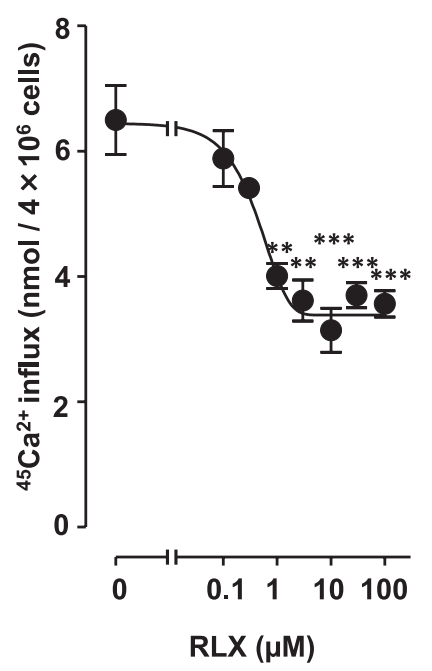

(C)

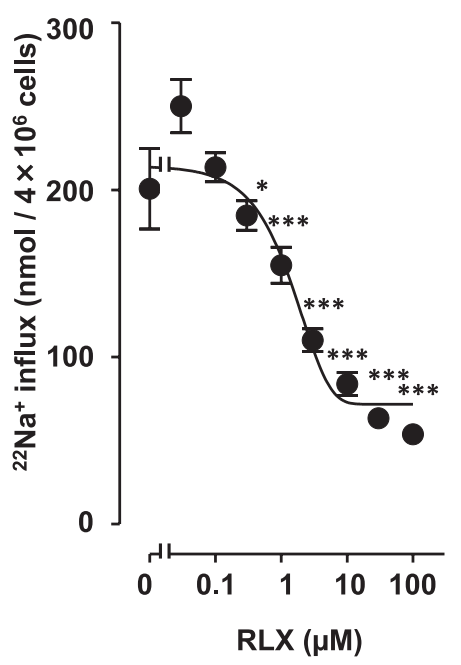

Fig. 5. Effects of various concentrations of raloxifene on $\mathrm{ACh}$-induced catecholamine secretion (A), ${ }^{45} \mathrm{Ca}^{2+}$ influx $(\mathrm{B})$, and ${ }^{22} \mathrm{Na}^{+}$ influx (C) in the cells. A) After preincubation of cells with various concentrations of raloxifene (RLX) for 10 min at $37^{\circ} \mathrm{C}$, cells $\left(10^{6} /\right.$ well $)$ were stimulated with ACh $(300 \mu \mathrm{M})$ in the presence of various concentrations of raloxifene for another $10 \mathrm{~min}$ at $37^{\circ} \mathrm{C}$. Catecholamines secreted were measured and expressed as a percentage of total catecholamines $(5.01 \pm 0.37 \mu \mathrm{g})$. B and C) After preincubation with various concentrations of raloxifene for $10 \mathrm{~min}$, cells $\left(4 \times 10^{6} / \mathrm{dish}\right)$ were incubated in the presence of various concentrations of raloxifene, $300 \mu \mathrm{M}$ ACh, $1.5 \mu \mathrm{Ci}$ of ${ }^{45} \mathrm{CaCl}_{2}$ (B), or ${ }^{22} \mathrm{NaCl}(\mathrm{C})$ for another $5 \mathrm{~min}$ at $37^{\circ} \mathrm{C} .{ }^{45} \mathrm{Ca}^{2+}$ influx and ${ }^{22} \mathrm{Na}^{+}$ influx were measured, and expressed as nmol $/ 4 \times 10^{6}$ cells. Data are the mean \pm S.E.M. of 4 separate experiments carried out in triplicate. ${ }^{*} P<0.05,{ }^{* *} P<0.01$, and $* * * P<0.001$; compared to ACh alone.

(A)

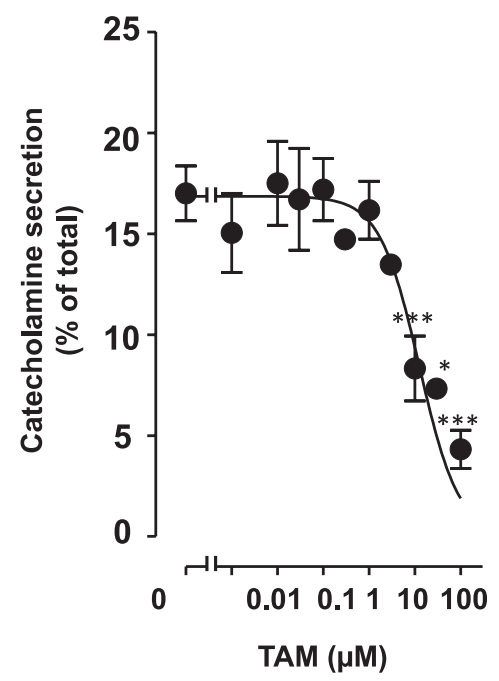

(B)

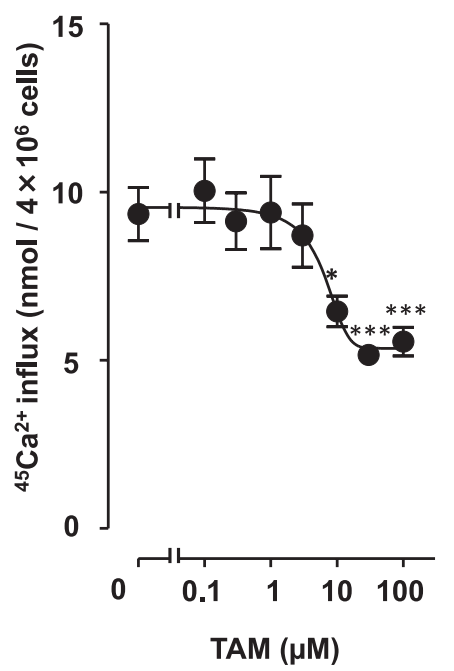

(C)

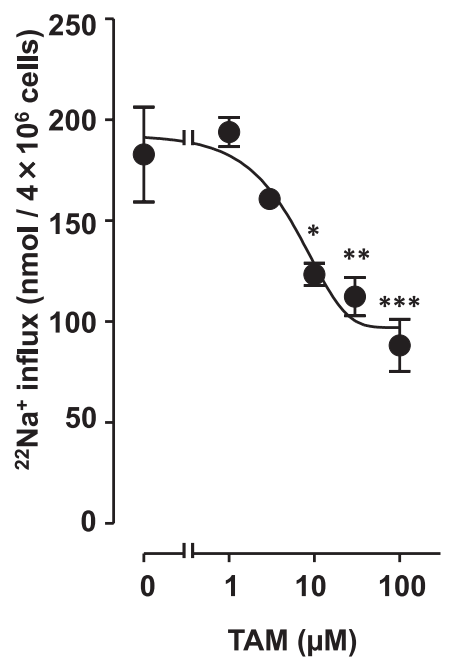

Fig. 6. Effects of various concentrations of tamoxifen on ACh-induced catecholamine secretion (A), ${ }^{45} \mathrm{Ca}^{2+}$ influx (B), and ${ }^{22} \mathrm{Na}{ }^{+}$ influx (C) in the cells. A) After preincubation of cells with various concentrations of tamoxifen (TAM) for 10 min at $37^{\circ} \mathrm{C}$, cells $\left(10^{6} /\right.$ well) were stimulated with $\mathrm{ACh}(300 \mu \mathrm{M})$ in the presence of various concentrations of tamoxifen for another 10 min at $37^{\circ} \mathrm{C}$. Catecholamines secreted were measured and expressed as a percentage of total catecholamines $(5.64 \pm 0.49 \mu \mathrm{g})$. B and C) After preincubation with various concentrations of tamoxifen for $10 \mathrm{~min}$, the cells $\left(4 \times 10^{6} / \mathrm{dish}\right)$ were incubated in the presence of various concentrations of tamoxifen, $300 \mu \mathrm{M} \mathrm{ACh}, 1.5 \mu \mathrm{Ci}$ of ${ }^{45} \mathrm{CaCl}_{2}(\mathrm{~B})$, or ${ }^{22} \mathrm{NaCl}(\mathrm{C})$ for another 5 min at $37^{\circ} \mathrm{C} .{ }^{45} \mathrm{Ca}^{2+}$ influx and ${ }^{22} \mathrm{Na}^{+}$influx were measured, and expressed as nmol $/ 4 \times 10^{6}$ cells. Data are the mean \pm S.E.M. of 4 separate experiments carried out in triplicate. ${ }^{*} P<0.05,{ }^{*} P<0.01$, and $* * * P<0.001$; compared to ACh alone. 
(A)
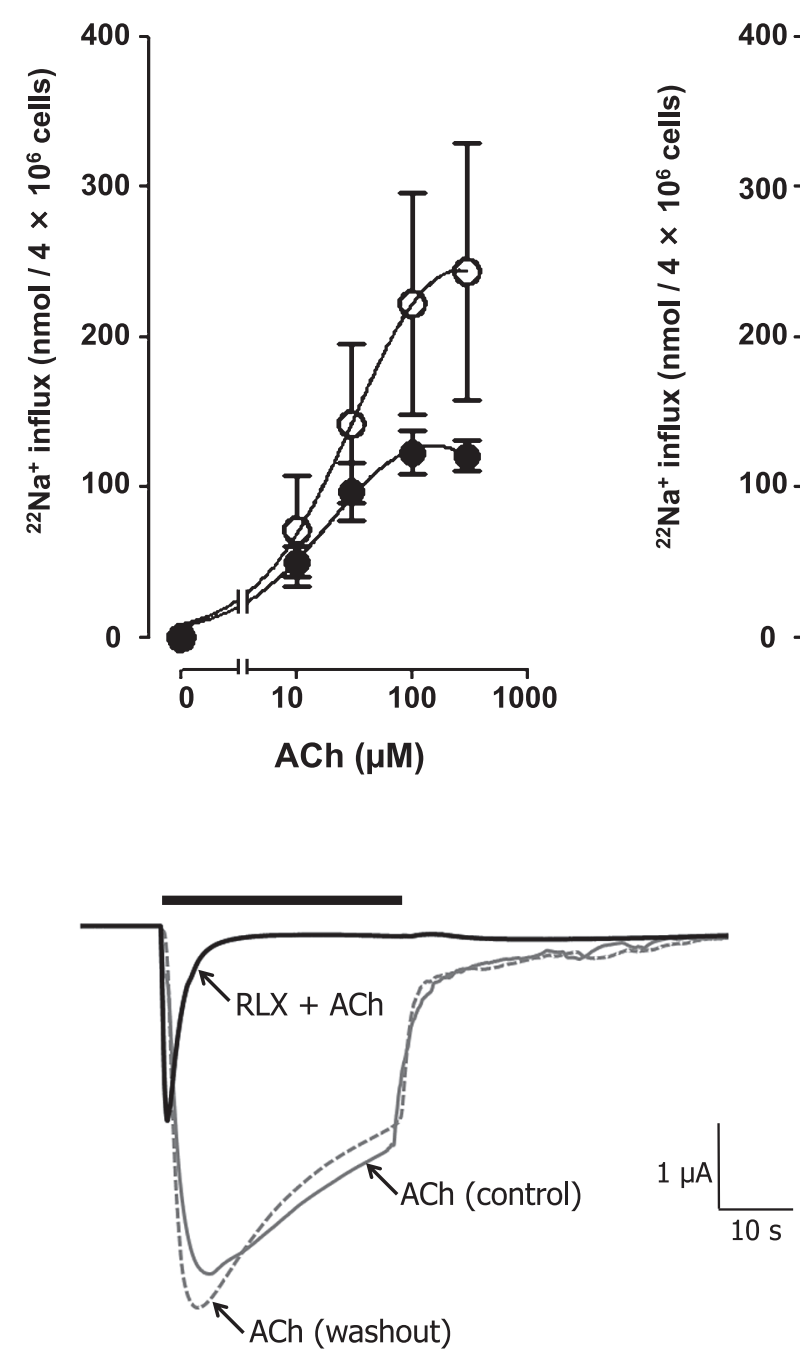

Fig. 8. Effect of raloxifene on ACh-induced response in nAChRs expressed in Xenopus oocytes. Representative current tracings obtained from the same Xenopus oocyte expressing rat $\alpha 4 \beta 2 \mathrm{nAChRs}$ were superimposed, demonstrating an inhibitory effect of raloxifene $(\mathrm{RLX}, 1 \mu \mathrm{M})$ on the current induced by the $\mathrm{EC}_{50}$ of $\mathrm{ACh}$. Traces represent the responses of $\mathrm{ACh}$ (control), in the presence of RLX $(\mathrm{RLX}+\mathrm{ACh})$, and 15-min washout [ACh (washout): dotted line]. The bar indicates the time of drug applications (ACh alone or RLX plus ACh), but it should be noted that RLX was pre-applied for $2 \mathrm{~min}$ before the coapplication with ACh.

Modulatory effects of raloxifene and tamoxifen on ${ }^{14} \mathrm{C}$ catecholamine synthesis and catecholamine secretion

In bovine adrenal medullary cells, we previously reported that $17 \beta-\mathrm{E}_{2}$ (12), environmental estrogenic pollutants (19), and phytoestrogens, such as daidzein (13) and resveratrol (14), stimulate catecholamine synthesis through plasma membrane estrogen receptors. A previous study reported that activation of membrane estrogen receptors increases intracellular $\mathrm{Ca}^{2+}$ concentrations and progesterone synthesis in rat hypothalamic astrocytes (20). In the present study, however, the stimulatory effect of tamoxifen on ${ }^{14} \mathrm{C}$-catecholamine synthesis may not be mediated through the plasma membrane estrogen receptors because it increased basal synthesis of ${ }^{14} \mathrm{C}$-catecholamines only at $100 \mathrm{nM}$. Furthermore, at higher concentrations raloxifene $(0.1-$ $1.0 \mu \mathrm{M})$ and tamoxifen $(1.0-10 \mu \mathrm{M})$ inhibited ${ }^{14} \mathrm{C}$ catecholamine synthesis. There was no relation between catecholamine synthesis and modulation of $\left[{ }^{3} \mathrm{H}\right] 17 \beta-\mathrm{E}_{2}$ binding induced by SERMs. From these present results, it seems that the interactions of the SERMs with plasma membrane estrogen receptors are not associated with catecholamine synthesis in the cells.

Both raloxifene $(1.0 \mu \mathrm{M})$ and tamoxifen $(10-100 \mu \mathrm{M})$ suppressed $\mathrm{ACh}$-induced ${ }^{14} \mathrm{C}$-catecholamine synthesis in a concentration-dependent manner. We previously reported that $\mathrm{ACh}$ activates nAChR-ion channels, thereby inducing $\mathrm{Na}^{+}$influx and then $\mathrm{Ca}^{2+}$ influx as well as catecholamine synthesis (10) and secretion (11). In the present study, raloxifene and tamoxifen both preferentially inhibited catecholamine secretion mediated through nAChRs but neither did so through voltage-dependent $\mathrm{Na}^{+}$channels or voltage-dependent $\mathrm{Ca}^{2+}$ channels. The present results were partially consistent with those of a previous report (7) that raloxifene at micromolar concentrations inhibited catecholamine output elicited by ACh or high potassium in perfused rat adrenal glands and cultured bovine adrenal medullary cells. In the present study, both SERMs suppressed ACh-induced ${ }^{45} \mathrm{Ca}^{2+}$ 
influx and ${ }^{22} \mathrm{Na}^{+}$influx in a concentration-dependent manner, similar to their suppression of catecholamine secretion and synthesis. It is likely that raloxifene and tamoxifen suppress ACh-induced catecholamine synthesis and secretion primarily by inhibiting $\mathrm{Na}^{+}$influx through nAChR-ion channels and subsequent $\mathrm{Ca}^{2+}$ influx through voltage-dependent $\mathrm{Ca}^{2+}$ channels.

We further investigated the inhibitory mechanisms underlying the effects of raloxifene and tamoxifen on nAChR-ion channels. Increased concentrations of ACh did not overcome the inhibitory effects of the SERMs on ACh-induced ${ }^{22} \mathrm{Na}^{+}$influx, suggesting that the SERMs act on the sites differently than they act on ACh binding sites of nAChR-ion channels. We confirmed that raloxifene directly and reversibly suppressed AChinduced $\mathrm{Na}^{+}$current in Xenopus oocytes expressing rat $\alpha 4 \beta 2 \mathrm{nAChR}$.

\section{Pharmacological significance of the effects of the SERMs on catecholamine synthesis and secretion}

The pharmacokinetic properties of raloxifene and tamoxifen in postmenopausal women and in women with breast cancer showed that the maximum plasma concentrations of raloxifene and tamoxifen were $2-3 \mathrm{nM}$ and $20-330 \mathrm{nM}$, respectively, during clinical treatments $(21,22)$. Tamoxifen, however, is reported to accumulate in tissues, resulting in 100-fold higher concentrations than in plasma after repeated administration of the drug during long-term treatment for breast cancer (23). Therefore, the concentrations of raloxifene and tamoxifen used in the present study should be high, compared to those plasma therapeutic concentrations, but they might be clinically relevant in the tissues.

Several lines of evidence have shown that the SERMs have both potentially adverse (24) and beneficial effects on brain functions such as cognition $(25,26)$ and neuroprotection (27). Indeed, raloxifene is reported to induce neurite outgrowth in estrogen receptor-positive PC12 cells (28). In the present study, we demonstrated that low concentration of tamoxifen $(100 \mathrm{nM})$ stimulates basal catecholamine synthesis, whereas at high concentrations, it inhibits basal and ACh-induced catecholamine synthesis and secretion. On the basis of the present results, it would be hypothesized that the SERMs negatively or positively modulate the functions of central noradrenergic or dopaminergic neurons, depending on their concentrations, by changing the synthesis and release of each neurotransmitter. To confirm this possibility, further in vivo studies are required in the near future.

In summary, we demonstrated that two SERMs, raloxifene and tamoxifen, allosterically interact with plasma membrane estrogen receptors, whereas at high concentrations each of them inhibits catecholamine synthesis and secretion induced by $\mathrm{ACh}$ in adrenal medullary cells and probably in peripheral and central sympathetic neurons.

\section{Acknowledgments}

This research was supported, in part, by Grants-in-Aid (23617035, 23590159, 23617036, and 24890286) for Scientific Research (C) from the Japan Society for the Promotion of Science. We are grateful to Dr. James A. Patrick (Division of Neuroscience, Baylor College of Medicine, Houston, TX, USA) for providing rat $\mathrm{nAChR}$ subunit $\mathrm{cD}$ NAs used in this study.

\section{Conflicts of Interest}

The authors have no conflict of interest to report.

\section{References}

1 MacGregor JI, Jordan VC. Basic guide to the mechanisms of antiestrogen action. Pharmacol Rev. 1998;50:151-196.

2 Smith CL, O'Malley BW. Coregulator function: a key to understanding tissue specificity of selective receptor modulators. Endocr Rev. 2004;25:45-71.

3 Jordan VC, Gapstur S, Morrow M. Selective estrogen receptor modulation and reduction in risk of breast cancer, osteoporosis, and coronary heart disease. J Natl Cancer Inst. 2001;93: 1449-1457.

4 Mauvais-Jarvis F, Clegg DJ, Hevener AL. The role of estrogens in control of energy balance and glucose homeostasis. Endocr Rev. 2013;34:309-338.

5 Yamaguchi K, Honda H, Wakisaka C, Tohei A, Kogo H. Effects of phytoestrogens on acetylcholine- and isoprenaline-induced vasodilation in rat aorta. Jpn J Pharmacol. 2001;87:67-73.

6 Nakazawa K, Ohno Y. Block by phytoestrogens of recombinant human neuronal nicotinic receptors. J Pharmacol Sci. 2003;93: $118-121$.

7 Machado JD, Alonso C, Morales A, Gomez JF, Borges R. Nongenomic regulation of the kinetics of exocytosis by estrogens. J Pharmacol Exp Ther. 2002;301:631-637.

8 Kim YJ, Hur EM, Park TJ, Kim KT. Nongenomic inhibition of catecholamine secretion by $17 \beta$-estradiol in PC12 cells. J Neurochem. 2000;74:2490-2496.

9 Weiner N. Regulation of norepinephrine biosynthesis. Annu Rev Pharmacol. 1970;10:273-290.

10 Yanagihara N, Wada A, Izumi F. Effects of $\alpha_{2}$-adrenergic agonists on carbachol-stimulated catecholamine synthesis in cultured bovine adrenal medullary cells. Biochem Pharmacol. 1987; 36:3823-3828.

11 Wada A, Takara H, Izumi F, Kobayashi H, Yanagihara N. Influx of ${ }^{22} \mathrm{Na}$ through acetylcholine receptor-associated $\mathrm{Na}$ channels: relationship between ${ }^{22} \mathrm{Na}$ influx, ${ }^{45} \mathrm{Ca}$ influx and secretion of catecholamines in cultured bovine adrenal medulla cells. Neuroscience. 1985;15:283-292.

12 Yanagihara N, Liu M, Toyohira Y, Tsutsui M, Ueno S, Shinohara $\mathrm{Y}$, et al. Stimulation of catecholamine synthesis through unique estrogen receptors in the bovine adrenomedullary plasma membrane by $17 \beta$-estradiol. Biochem Biophys Res Commun. 
2006;339:548-553.

13 Liu M, Yanagihara N, Toyohira Y, Tsutsui M, Ueno S, Shinohara Y. Dual effects of daidzein, a soy isoflavone, on catecholamine synthesis and secretion in cultured bovine adrenal medullary cells. Endocrinology. 2007;148:5348-5354.

14 Shinohara Y, Toyohira Y, Ueno S, Liu M, Tsutsui M, Yanagihara $\mathrm{N}$. Effects of resveratrol, a grape polyphenol, on catecholamine secretion and synthesis in cultured bovine adrenal medullary cells. Biochem Pharmacol. 2007;74:1608-1618.

15 Yanagihara N, Isosaki M, Ohuchi T, Oka M. Muscarinic receptormediated increase in cyclic GMP level in isolated bovine adrenal medullary cells. FEBS Lett. 1979;105:296-298.

16 Yanagihara N, Oishi Y, Yamamoto H, Tsutsui M, Kondoh J, Sugiura T, et al. Phosphorylation of chromogranin A and catecholamine secretion stimulated by elevation of intracellular $\mathrm{Ca}^{2+}$ in cultured bovine adrenal medullary cells. J Biol Chem. 1996; 271:17463-17468.

17 Ueno S, Tsutsui M, Toyohira Y, Minami K, Yanagihara N. Sites of positive allosteric modulation by neurosteroids on ionotropic $\gamma$-aminobutyric acid receptor subunits. FEBS Lett. 2004;566: 213-217.

18 Horishita T, Ueno S, Yanagihara N, Sudo Y, Uezono Y, Okura D, et al. Inhibition by pregnenolone sulphate, a metabolite of the neurosteroid pregnenolone, of voltage-gated sodium channels expressed in Xenopus oocytes. J Pharmacol Sci. 2012;120: 54-58.

19 Yanagihara N, Toyohira Y, Ueno S, Tsutsui M, Utsunomiya K, Liu M, et al. Stimulation of catecholamine synthesis by environmental estrogenic pollutants. Endocrinology. 2005;146:265272.

20 Kuo J, Hamid N, Bondar G, Prossnitz ER, Micevych P. Membrane estrogen receptors stimulate intracellular calcium release and progesterone synthesis in hypothalamic astrocytes.
J Neurosci. 2010;30:12950-12957.

21 Wada T, Koyama H, Takahashi Y, Nishizawa Y, Iwanaga T, Aoki Y, et al. [Tamoxifen therapy in locally advanced primary and recurrent breast cancer (author's transl)]. Nihon Gan Chiryo Gakkai Shi. 1979;14:819-824. (text in Japanese)

22 Traina TA, Poggesi I, Robson M, Asnis A, Duncan BA, Heerdt $\mathrm{A}$, et al. Pharmacokinetics and tolerability of exemestane in combination with raloxifene in postmenopausal women with a history of breast cancer. Breast Cancer Res Treat. 2008;111: 377-388.

23 Lien EA, Solheim E, Ueland PM. Distribution of tamoxifen and its metabolites in rat and human tissues during steady-state treatment. Cancer Res. 1991;51:4837-4844.

24 Espeland MA, Shumaker SA, Limacher M, Rapp SR, Bevers $\mathrm{TB}$, Barad DH, et al. Relative effects of tamoxifen, raloxifene, and conjugated equine estrogens on cognition. J Womens Health (Larchmt). 2010;19:371-379.

25 Yaffe K, Krueger K, Cummings SR, Blackwell T, Henderson VW, Sarkar S, et al. Effect of raloxifene on prevention of dementia and cognitive impairment in older women: the Multiple Outcomes of Raloxifene Evaluation (MORE) randomized trial. Am J Psychiatry. 2005;162:683-690.

26 Legault C, Maki PM, Resnick SM, Coker L, Hogan P, Bevers $\mathrm{TB}$, et al. Effects of tamoxifen and raloxifene on memory and other cognitive abilities: cognition in the study of tamoxifen and raloxifene. J Clin Oncol. 2009;27:5144-5152.

27 Kuo YM, Chen HH, Shieh CC, Chuang KP, Cherng CG, Yu L. 4-Hydroxytamoxifen attenuates methamphetamine-induced nigrostriatal dopaminergic toxicity in intact and gonadetomized mice. J Neurochem. 2003;87:1436-1443.

28 Nilsen J, Mor G, Naftolin F. Raloxifene induces neurite outgrowth in estrogen receptor positive PC12 cells. Menopause. 1998;5:211-216. 